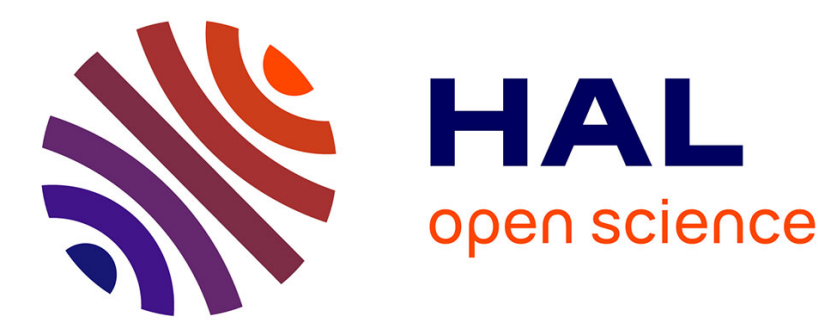

\title{
Special issue on current concepts in honeybee neurophysiology
}

\author{
Bernd Grünewald
}

\section{To cite this version:}

Bernd Grünewald. Special issue on current concepts in honeybee neurophysiology. Apidologie, 2012, 43 (3), pp.227-228. 10.1007/s13592-012-0133-1 . hal-01003655

\section{HAL Id: hal-01003655 https://hal.science/hal-01003655}

Submitted on 1 Jan 2012

HAL is a multi-disciplinary open access archive for the deposit and dissemination of scientific research documents, whether they are published or not. The documents may come from teaching and research institutions in France or abroad, or from public or private research centers.
L'archive ouverte pluridisciplinaire HAL, est destinée au dépôt et à la diffusion de documents scientifiques de niveau recherche, publiés ou non, émanant des établissements d'enseignement et de recherche français ou étrangers, des laboratoires publics ou privés. 


\section{Special issue on current concepts in honeybee neurophysiology}

The honeybee has a special place among the model organisms of modern neuroscience. What makes it such an attractive system is the fact that it is a social invertebrate with its whole genome sequenced showing a rich behavior and yet has a rather small brain. Thus, the relation between the activity of single neurons and the behavior it controls is often quite straightforward. Several classical behavioral studies on honeybees dealt with navigation. Consequently, the first paper of this special issue is an original article by Randolf Menzel et al. studying the orientation properties of individual forager bees. Using harmonic radar tracking, Menzel et al. showed that foragers use complex navigation memories utilizing flight vector integration and map-like representations. Such studies open the question of the cognitive abilities of a rather small and limited brain. The honeybee brain measures about $1 \mathrm{~mm}^{2}$ and contains just about one million neurons. However, it controls highly complex social, orientation, and learning behaviors.

The sensory physiology of the honeybee is discussed in three reviews. Aurore AvarguesWeber et al. summarize the visual information processing in the bee brain. They integrate behavioral observations, functional anatomy and physiology of honeybee vision into their comprehensive overview. During the last decade, many studies were published with exciting new insights into olfactory information processing within the bee brain. Martin Nawrot reviews

Corresponding author: B. Grünewald, b.gruenewald@bio.uni-frankfurt.de experimental and theoretical approaches analyzing how odors and odor mixture information are encoded within the antennal lobe and the mushroom body of the honeybee brain. David Jarriault and Alison Mercer provide an overview on the queen pheromone. They particularly review new data on the mechanisms of how queen mandibular pheromone acts on worker bees.

Learning and memory is yet another highly dynamic field of honeybee neurobiological research. How does neural plasticity translate into behavioral changes and how is the physiology of neurons altered by experience? These questions are discussed in two reviews. Sophie Himmelreich and Bernd Grünewald integrate the available electrophysiological and optophysiological studies dealing with the neurobiological correlates of olfactory conditioning. They present a physiological model for discussing how neurons detect the coincident appearance of the conditioned and reward stimulus. One step further into the molecular signaling processes of olfactory learning goes Uli Müller. His review presents the various kinases, transmitters, and receptors that are specifically involved during the different memory phases on one hand and in different brain areas of the honeybee brain on the other hand.

Bees encounter several threats in an anthropogenic environment. In their review, Wolfgang Blenau et al. discuss how "natural" acaricides such as essential oils and the synthetic formamidine pesticides act within the nervous system of insects and mites. These substances most likely target biogenic amine receptors and thus influence behavior and physiology. Luc Belzunces 
et al. provide a comprehensive overview on the neural and behavioral effects of insecticides. Their article provides scientific information for a controversially debated subject. How and which insecticides may affect the behavior and the vitality of honeybees?

Thus, this issue brings together analyses of all levels, starting from the molecular level (ion channels and protein kinases), to the cellular and the neural network level (antennal lobes, mushroom bodies, retina and optic lobes) and to the behavioral level (learning, navigation, pheromonal communication). It provides a cross section through many aspects of today's honeybee neuroscience and may serve for a better understanding of the neural control of adaptive behavior of the honeybee.

Bernd Grünewald 